\title{
Simultaneous RP HPLC Determination of Camylofin Dihydrochloride and Diclofenac Potassium in Pharmaceutical Preparations
}

\author{
M.V. Rathnam*, R. R. Singh \\ Department of Chemistry, B.N. Bandodkar College of Science, Chendani, Thane-400 601, Maharashtra, India, Tel: 0119125336507
}

\begin{abstract}
A simple, fast and precise reversed phase high performance liquid chromatographic method has been developed for the simultaneous determination of Camylofin dihydrochloride and Diclofenac Potassium using Methylparaben as an internal standard. Efficient_chromatographic separation was achieved on Inertsil $\mathrm{C}_{18}$ column $(250 \mathrm{~mm} \times 4.6 \mathrm{~mm}$, $5 \mu \mathrm{m})$ as stationary phase with a mobile phase comprising of $0.05 \mathrm{M} \mathrm{KH}_{2} \mathrm{PO}_{4}$ in water : Methanol $(35: 65, \mathrm{v} / \mathrm{v})$ at a flow rate of $1.5 \mathrm{~mL} \mathrm{~min}{ }^{-1}$, column temperature of $27^{\circ} \mathrm{C}$ and UV detection at $220 \mathrm{~nm}$. The retention time of Methylparaben, Camylofin dihydrochloride and Diclofenac potassium were $3.60 \mathrm{~min}, 4.85 \mathrm{~min}$ and $13.10 \mathrm{~min}$ respectively. The proposed method was validated for linearity, accuracy, precision, sensitivity, robustness and solution stability. Linearity, accuracy and precision were found to be acceptable over the ranges of $250-750 \mu \mathrm{g} \mathrm{mL}^{-1}$ for both camylofin dihydrochloride and diclofenac potassium. The test solution was found to be stable for $48 \mathrm{~h}$. It can be conveniently adopted for routine quality control analysis.
\end{abstract}

Keywords: Camylofin dihydrochloride; Diclofenac potassium; Validation; Liquid Chromatography; Pharmaceutical preparations

\section{Introduction}

Camylofin

dihydrochloride

is

3-methylbutyl

2-(2-diethylaminoethylamino)-2-phenyl-acetate hydrochloride is a drug used an antispasmodic. Diclofenac potassium is potassium-[(2, 6-dichlorophenyl) aminol-phenyl acetate. It is a potassium salt of an aryl acetic acid derivative. It possesses analgesic, anti-inflammatory, and antipyretic activity. The structure of the drug is shown in (Figure 1) One such combination contains $25 \mathrm{mg}$ of Camylofin dihydrochloride and $25 \mathrm{mg}$ of Diclofenac potassium. The literature revealed no method was available for simultaneous determination of this drug in such pharmaceutical preparation by HPLC [1-5]. Therefore an HPLC method was developed for determination of Camylofin dihydrochloride and Diclofenac potassium from their dosage form. The method described is simple, fast, precise and accurate for simultaneous determination of Camylofin dihydrochloride and Diclofenac potassium from pharmaceutical preparation.

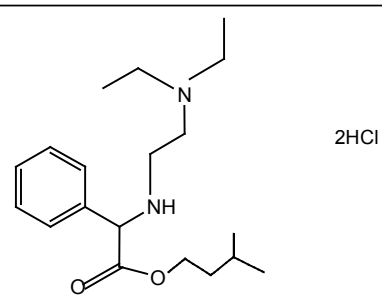

Diclofenac potassium $\left(\mathrm{C}_{14} \mathrm{H}_{10} \mathrm{Cl}_{2} \mathrm{KNO}_{2}\right)$

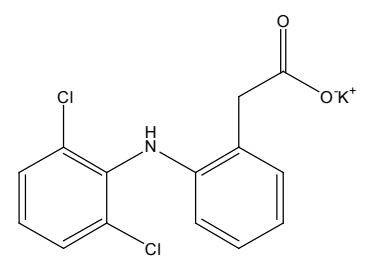

Figure 1: Structures of Camylofin dihydrochloride and Diclofenac potassium Camylofin dihydrochloride $\left(\mathrm{C}_{19} \mathrm{H}_{32} \mathrm{~N}_{2} \mathrm{O}_{2}, 2 \mathrm{HCl}\right)$.

\section{Material and Methods}

\section{Chemicals}

Anaspas tablets manufactured by Khandelwal lab, India were procured from the market. Anaspas tablets is a combination of Camylofin dihydrochloride $25 \mathrm{mg}$ and Diclofenac potassium $25 \mathrm{mg}$. Potassium dihydrogen orthophosphate and methanol were from Qualigens. Double distilled water was employed throughout the work. All dilutions were performed in standard volumetric flasks.

\section{LC instrument and condition}

To develop a suitable LC method for the analysis of Camylofin dihydrochloride and Diclofenac potassium in their dosage form, different mobile phases were tried. The criteria employed for selecting the mobile phase for the analyses of the drugs were cost involved, time required for the analysis and better separation of drugs. Chromatographic separation was preformed with Shimadzu LC 2010 High performance liquid chromatography having HPLC isocratic pump, equipped with auto sampler and a photo-diode array detector. The UV spectrums of Camylofin dihydrochloride and Diclofenac potassium were scanned on photo diode array detector for selecting the working wavelength. Peak purity of Camylofin dihydrochloride and Diclofenac potassium was checked using photo diode array detector. Chromatograms and data were recorded by means of Class VP software. Inertsil $\mathrm{C}_{18}$ column $(250 \mathrm{~mm} \times 4.6$ $\mathrm{mm}, 5 \mu \mathrm{m}$ particle) was used for the analysis. The mobile phase

*Corresponding author: M.V. Rathnam, Department of Chemistry, B.N Bandodkar College of Science, Chendani, Thane-400 601, Maharashtra, India, Tel: 01191 25336507; E-mail: kumarrajeevs@gmail.com

Received August 30, 2010; Accepted September 27, 2010 Published September 30, 2010

Citation: Rathnam MV, Singh RR (2010) Simultaneous RP HPLC Determination of Camylofin Dihydrochloride and Diclofenac Potassium in Pharmaceutical Preparations. Pharm Anal Acta 1:108. doi:10.4172/2153-2435.1000108

Copyright: () 2010 Rathnam MV, et al. This is an open-access article distributed under the terms of the Creative Commons Attribution License, which permits unrestricted use, distribution, and reproduction in any medium, provided the original author and source are credited. 


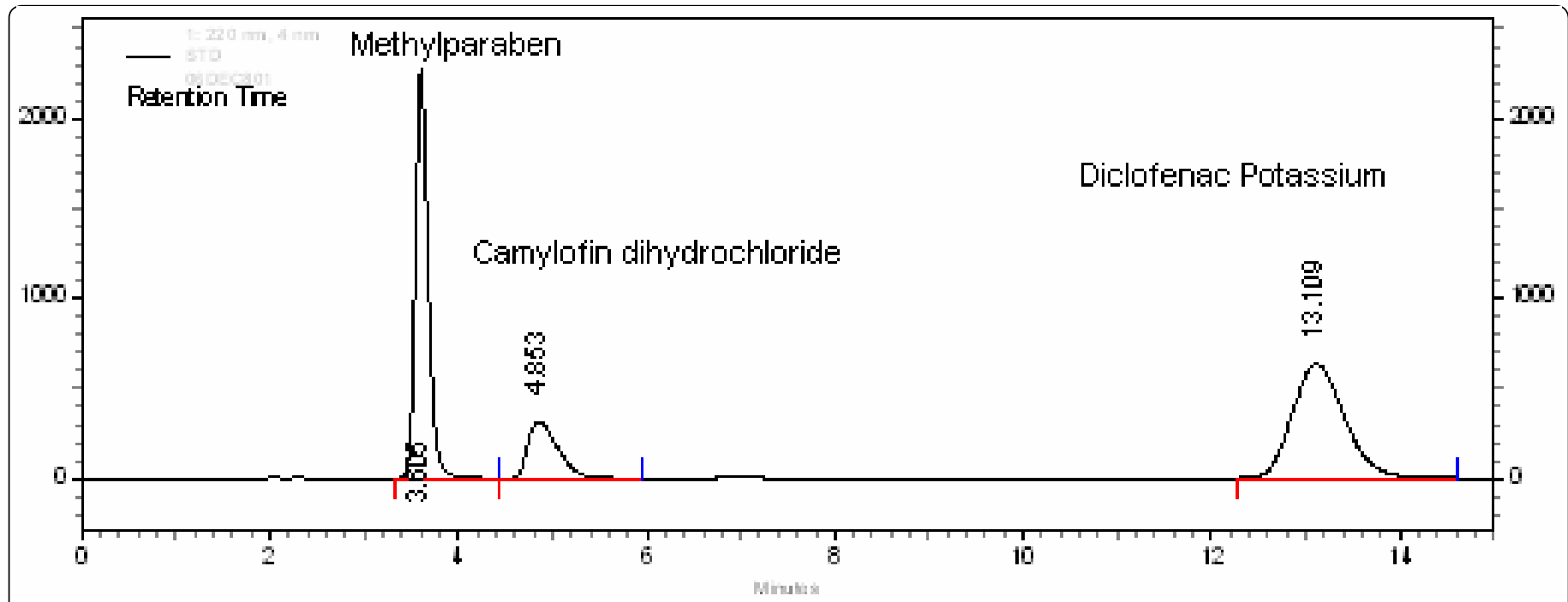

Figure 2: Chromatogram of Camylofin dihydrochloride and Diclofenac potassium with Methylparaben (internal standard) in standard preparation.

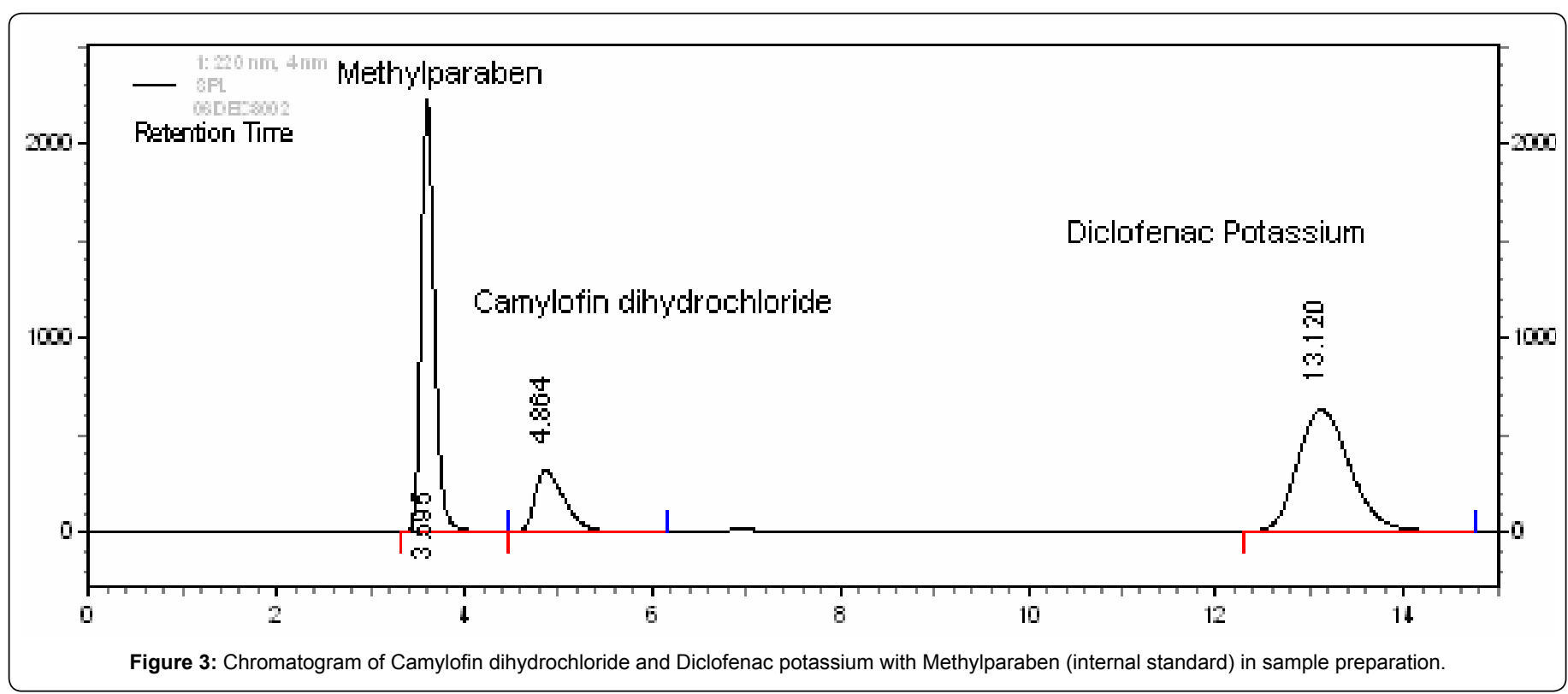

comprising of $0.05 \mathrm{M} \mathrm{KH}_{2} \mathrm{PO}_{4}$ in water: Methanol $(35: 65 \mathrm{v} / \mathrm{V})$ was used. The system was run at a flow rate of $1.5 \mathrm{~mL} \mathrm{~min}^{-1}$ and $20 \mu \mathrm{L}$ of sample was injected in the chromatographic system. The column temperature was maintained at $27^{\circ} \mathrm{C}$ and detection wavelength was set at $220 \mathrm{~nm}$ for simultaneous determination of Camylofin dihydrochloride and Diclofenac potassium. A typical HPLC chromatogram for simultaneous determination of Camylofin dihydrochloride and Diclofenac potassium from pharmaceutical formulation is shown in (Figure 3).

Preparation of Standard Stock Solutions: The stock solution of Camylofin dihydrochloride $\left(2500 \mu \mathrm{g} \mathrm{mL}^{-1}\right)$ was prepared by dissolving $250.2 \mathrm{mg}$ of Camylofin dihydrochloride $(99.9 \%)$ in methanol in a standard $100 \mathrm{~mL}$ volumetric flask (stock solution A). The stock solution of Diclofenac potassium $\left(2500 \mu \mathrm{g} \mathrm{mL}^{-1}\right)$ was prepared by dissolving 250.4 $\mathrm{mg}$ of Diclofenac potassium $(99.6 \%)$ in methanol in a standard $100 \mathrm{~mL}$ volumetric flask (stock solution B). Internal standard (methyl paraben) stock solution $\left(5000 \mu \mathrm{g} \mathrm{mL}^{-1}\right)$ was prepared by dissolving $499.8 \mathrm{mg}$ of methyl paraben in methanol in a $100 \mathrm{~mL}$ standard volumetric flask (stock solution C).
Working standard solution: Transferred $10.0 \mathrm{~mL}$ of each stock solution A, B \& C to a $50 \mathrm{~mL}$ volumetric flask and diluted up to the mark with methanol.

Preparation of sample solution: Twenty tablets were weighed and their average weight was calculated. The tablets were crushed into a homogeneous powder and quantity equivalents to ten tablets were transferred in a $100 \mathrm{~mL}$ volumetric flask, dissolved in methanol and filtered through Whatman no. 41 filter paper. The $10.0 \mathrm{~mL}$ of filtrate was quantitatively transferred to a $50 \mathrm{~mL}$ volumetric flask, $10.0 \mathrm{~mL}$ of internal standard solution was added to it, and solution was diluted up to the mark with methanol.

\section{Results and Discussion}

\section{Method development}

Several mobile phases using different organic solvents as part of mobile phase were tried. Water and acetonitrile in the ratio of 500:500, v/v was chosen for initial trail with a $25 \mathrm{~cm}$ length, $4.6 \mathrm{~mm}$ 


\begin{tabular}{|l|l|l|l|}
\hline Parameters & Methylparaben (IS) & Camylofin dihydrochloride & $\begin{array}{l}\text { Diclofenac } \\
\text { potassium }\end{array}$ \\
\hline Resolution & - & 2.94 & 10.32 \\
\hline Tailing factor & 1.29 & 1.69 & 1.20 \\
\hline Theoretical plates & 3034 & 1097 & 2676 \\
\hline
\end{tabular}

Table 1: Result of System suitability.

\begin{tabular}{|l|l|l|l|}
\hline Analyte & Slope & Intercept & Correlation coefficient $\left(r^{2}\right) \quad(n=7)$ \\
\hline Camylofin dihydrochloride & 0.001 & -0.006 & 0.9993 \\
\hline Diclofenac potassium & 0.002 & 0.002 & 0.9999 \\
\hline
\end{tabular}

Table 2: Results of Linearity.

\begin{tabular}{|l|l|l|}
\hline Results & Camylofin dihydrochloride & Diclofenac potassium \\
\hline Drug found in mg/tab (mean) & 25.03 & 25.10 \\
\hline \% Mean Assay & 100.1 & 100.4 \\
\hline \% RSD & 0.49 & 0.40 \\
\hline
\end{tabular}

Table 3: Results of Assay experiment.

ID and 5 micron particle size C-18 stationary phase. Flow rate was 1.0 $\mathrm{mL} \mathrm{min}^{-1}$. When test solution was injected the resolution between Methylparaben and Camylofin dihydrochloride was less $(<1.2)$. Results obtained with $25 \mathrm{~cm}$ length, $4.6 \mathrm{~mm}$ ID and 5 micron particle size C-8 column showed lesser resolution between Methylparaben and Camylofin dihydrochloride was less $(<1.0)$.

To improve the resolution between Methylparaben and Camylofin dihydrochloride, water and methanol in the ratio 500:500, v/v was used as a mobile phase. When system suitability solution was injected in the above conditions the resolution between Methylparaben and Camylofin dihydrochloride was greater than 2.0, but the tailing factor of Camylofin dihydrochloride was greater than 2.2 and the retention time of Diclofenac potassium was found to be $\sim 29 \mathrm{~min}$. To further improve the tailing factor of Camylofin dihydrochloride and the retention time of Diclofenac potassium the ratio of water and methanol was changed. A mixture of water and methanol in the ratio of 350:650, v/v was used. Resolution between all the peaks were achieved but the peak shape of Camylofin dihydrochloride was not satisfactory. Also the tailing factor of Camylofin dihydrochloride was $\sim 2.0$. To improve the peak shape and tailing factor of Camylofin dihydrochloride, a buffer solution consisting of $0.05 \mathrm{M} \mathrm{K}_{2} \mathrm{HPO}_{4}$ solution was used instead of water. A mobile phase consisting of $0.05 \mathrm{M} \mathrm{K}_{2} \mathrm{HPO}_{4}$ solution and methanol in the ratio of 350:650,v/v was used. The peak shape of diclofenac potassium was not good. Hence buffer solution was selected at acidic side. When acidic buffer consisting of $0.05 \mathrm{M} \mathrm{KH}_{2} \mathrm{PO}_{4}$ solution and methanol in the ratio of $350: 650, v / v$ was used, good peak shape and greater resolution between Methylparaben, Camylofin dihydrochloride and Diclofenac potassium was observed in the system suitability solution. The resolution was greater than 2.0 and the tailing factor was less than 2.0 for all the peaks. The total run time of the chromatogram was not more than $15 \mathrm{~min}$.

HPLC columns played a major role in achieving satisfactory separation between the peaks. When C8 column (Inertsil C8, $4.6 \mathrm{x}$ $250 \mathrm{~mm}, 5 \mu$ ) was used the resolution between Methylparaben and Camylofin dihydrochloride was less (Resolution $<1.5$ ). To improve the resolution a column with more carbon loading i.e. C18 was selected (Inertsil C18, 4.6 x $250 \mathrm{~mm}, 5 \mathrm{u}$ ). Satisfactory peak shape and good resolution were observed between all the peaks.

In the optimized conditions Methylparaben, Camylofin dihydrochloride and diclofenac potassium were well separated with a resolution greater than 2.0 and the typical retention times of Methylparaben, Camylofin dihydrochloride and Diclofenac potassium were $3.60 \mathrm{~min}, 4.85 \mathrm{~min}$ and $13.10 \mathrm{~min}$ respectively.

\section{System suitability}

System suitability tests are used to verify that the reproducibility of the equipment is adequate for the analysis to be carried out. System suitability tests were performed as per the general chapter $<621>$ in USP 32 NF 27 to confirm the suitability and reproducibility of the system. The test was carried out by injecting $20-\mu \mathrm{L}$ standard solutions of Camylofin dihydrochloride, Diclofenac potassium of strengths $500 \mu \mathrm{g} \mathrm{mL} \mathrm{m}^{-1}$ using methyl paraben as an internal standard. Five replicate injections were made. The \%RSD values of Camylofin dihydrochloride and Diclofenac potassium were 0.31 and 0.18 respectively. The $\% \mathrm{RSD}$ values were found to be satisfactory and meeting the requirements of the general chapter $<621>$ in USP 32 NF 27 (\%RSD not more than $2.0 \%$ ). Theoretical plates, resolution, tailing factor were determined and are presented in (Table 1)

\section{Method Validation}

Method validation was done as per ICH guidelines [6-7].

\section{Linearity}

Linearity was evaluated by analysis of working standard solutions of Camylofin dihydrochloride and Diclofenac potassium of seven different concentrations. The range of linearity was from $250-750 \mu \mathrm{g}$ $\mathrm{mL}^{-1}$ for both Camylofin dihydrochloride and Diclofenac potassium. The peak area ratio and concentration of each drug was subjected to regression analysis to calculate the calibration equations and correlation coefficients. The regression data obtained for the Camylofin dihydrochloride and Diclofenac potassium is represented in (Table 2.) The result shows that with-in the concentration range mentioned above, there was an excellent correlation between peak area ratio and concentration.

\section{Sensitivity}

Sensitivity was determined by establishing the limit of detection (LOD) and limit of quantification (LOQ). The limit of detection (LOD) and limit of quantitation (LOQ) were established at signal-to-noise ratio of 3:1 and 10:1 respectively. The LOD and LOQ of Camylofin dihydrochloride and Diclofenac potassium were experimentally determined by six injections of each drug. The LOD of Camylofin dihydrochloride and Diclofenac potassium was found to be $0.05 \mu \mathrm{g}$ $\mathrm{mL}^{-1} \& 0.08 \mu \mathrm{g} \mathrm{mL}^{-1}$ respectively. The LOQ of Camylofin dihydrochloride and Diclofenac potassium was found to be $0.2 \mu \mathrm{g} \mathrm{mL}^{-1} \& 0.3 \mu \mathrm{g} \mathrm{mL}$ respectively.

\section{Precision}

Repeatability was studied by carrying out system precision. System precision was determined from results for six replicate injections of the mixed standard solutions. The relative standard deviation (RSD) was less than $2 \%$. Method precision was determined from results from six independent determinations at $100 \%$ of the test concentrations of Camylofin dihydrochloride and Diclofenac potassium in the product. The \% RSD for Camylofin dihydrochloride and Diclofenac potassium was found to be 0.49 and 0.40 respectively. Refer (Table 3).

\section{Ruggedness}

Ruggedness study was done by injecting six individual sample preparations at $100 \%$ of the test concentrations of Camylofin dihydrochloride and Diclofenac potassium on different day and different HPLC system. The mean \% Assay obtained was compared with mean \% Assay of precision study. The relative standard deviation 
Citation: Rathnam MV, Singh RR (2010) Simultaneous RP HPLC Determination of Camylofin Dihydrochloride and Diclofenac Potassium in Pharmaceutical Preparations. Pharm Anal Acta 1:108. doi:10.4172/2153-2435.1000108

Page 4 of 4

\begin{tabular}{|l|l|l|}
\hline Results & Camylofin dihydrochloride & Diclofenac potassium \\
\hline Drug found in mg/tab (mean) & 24.93 & 25.02 \\
\hline \% Mean Assay & 99.7 & 100.1 \\
\hline$\%$ RSD & 0.67 & 0.48 \\
\hline \% Difference w.r.t. Precision & 0.4 & 0.3 \\
\hline
\end{tabular}

Table 4: Ruggedness of Assay experiment.

\begin{tabular}{|c|c|c|c|c|c|c|}
\hline Analyte & Initial conc. (ppm) & Conc. added (ppm) & Total conc. (ppm) & Conc. found (ppm) & $\%$ RSD $n=3$ & $\%$ Recovery \\
\hline \multirow{4}{*}{ Camylofin dihydrochloride } & 500 & 0 & 500.0 & 501.57 & 0.59 & 100.3 \\
\hline & 500 & 50.0 & 550.0 & 548.50 & 0.36 & 99.7 \\
\hline & 500 & 100.0 & 600.0 & 602.20 & 0.23 & 100.4 \\
\hline & 500 & 150.0 & 650.0 & 650.23 & 0.23 & 100.0 \\
\hline \multirow{3}{*}{ Diclofenac potassium } & 500 & 50.0 & 550.0 & 550.16 & 0.12 & 100.0 \\
\hline & 500 & 100.0 & 600.0 & 600.47 & 0.16 & 100.4 \\
\hline & 500 & 150.0 & 650.0 & 649.95 & 0.12 & 100.3 \\
\hline
\end{tabular}

Table 5: Results of Accuracy experiment.

(RSD) was less than $2 \%$. The \% RSD for Camylofin dihydrochloride and Diclofenac potassium was found to be 0.67 and 0.48 respectively. Refer (Table 4).

\section{Accuracy}

To study accuracy of the method, recovery experiment was carried out by applying the standard addition method. A known quantity of drug substance corresponding to $50 \%, 100 \%$ and $150 \%$ of the label claim of drug were added, to determine if there are positive or negative interferences from excipients present in the formulation. Each set of addition were repeated three times .The accuracy was expressed as the percentage of analytes recovered by the assay. (Table 5) lists the recoveries of the drug from a series of spiked concentrations. The results indicate the method is highly accurate for simultaneous determination of Camylofin dihydrochloride and Diclofenac potassium.

\section{Robustness}

By deliberate change in experimental condition the resolution between Methylparaben, Camylofin dihydrochloride and Diclofenac potassium were evaluated. To study the effect of flow rate on system suitability parameters, 0.2 units changed i.e. 1.3 and $1.7 \mathrm{~mL} \mathrm{~min}^{-1}$. The effect of column temperature was studied at $22^{\circ} \mathrm{C}$ and $32^{\circ} \mathrm{C}$. In all the above varied conditions, the components of the mobile phase were held constant. The resolution between the peak between Methylparaben and Camylofin dihydrochloride was greater than 2.0 and Camylofin dihydrochloride and Diclofenac potassium was greater than 9.5 .

\section{Solution stability and mobile phase stability}

The solution stability of Camylofin dihydrochloride and Diclofenac potassium was carried out by leaving the test solutions of sample in a tightly capped volumetric flask at room temperature for $48 \mathrm{~h}$. The same sample solutions were assayed for $6 \mathrm{~h}$ interval up to the study period against freshly prepared standard solution.

Mobile phase stability was also carried out for $48 \mathrm{~h}$ by injecting the freshly prepared sample solutions for every $6 \mathrm{~h}$ interval. Content of Camylofin dihydrochloride and Diclofenac potassium were checked in the test solutions. Mobile phase prepared was kept constant during the study period. The \% RSD of assay of Camylofin dihydrochloride and Diclofenac potassium during solution stability and mobile phase stability experiments was within 1.0 . No significant changes were observed in the content of Camylofin dihydrochloride and Diclofenac potassium during solution stability and mobile phase stability experiments. Sample solutions and mobile phase used during the experiment were stable upto the study period of $48 \mathrm{~h}$.

\section{Conclusion}

The RP-LC method developed for quantitative determination of Camylofin dihydrochloride and Diclofenac potassium is precise, accurate and specific. The method was completely validated showing satisfactory data for all the method validation parameters tested. The developed method is stability indicating and can be used for routine analysis of production samples and also to check the stability of Camylofin dihydrochloride and Diclofenac potassium.

\section{References}

1. Elbarbry FA, Mabrouk MM, El-Dway MA (2007) Determination of the analgesic components of Spasmomigraine tablet by liquid chromatography with ultraviolet detection. J AOAC Int 90: 94-101.

2. Hinz B, Chevts J, Renner B, Wuttke H, Rau T, et al. (2007) Bioavailability of diclofenac potassium at low doses. Br J Clin Pharmacol 59: 80-84.

3. G Subramanian, P Musmade, S Agarwal, N Udupa (2004) Simultaneous RP HPLC estimation of tinidazole, diclofenac potassium and paracetamol in tablets. Indian journal of pharmaceutical sciences 66: 694-696.

4. Barde PS, Desai AY, Roy MNS, Vaidya VV (2008) Simultaneous RP HPLC determination of Camylofin dihydrochloride in Pharmaceutical preparation. TS Journal $7(10)$

5. Singh RR, Rathnam MV, Vegesna R (2008) Simultaneous RP HPLC determination of Camylofin dihydrochloride and Paracetamol in Pharmaceutical preparations.TSI Journal $7(11)$.

6. Snyder LR, Kirland JJ, Glajch JL (1997) Practical HPLC method development $2^{\text {nd }}$ edition, John Wiley and sons, Inc., USA.

7. ICH (1997) Validation of analytical procedures: methodology, ICH harmonized tripartite guidelines. 